
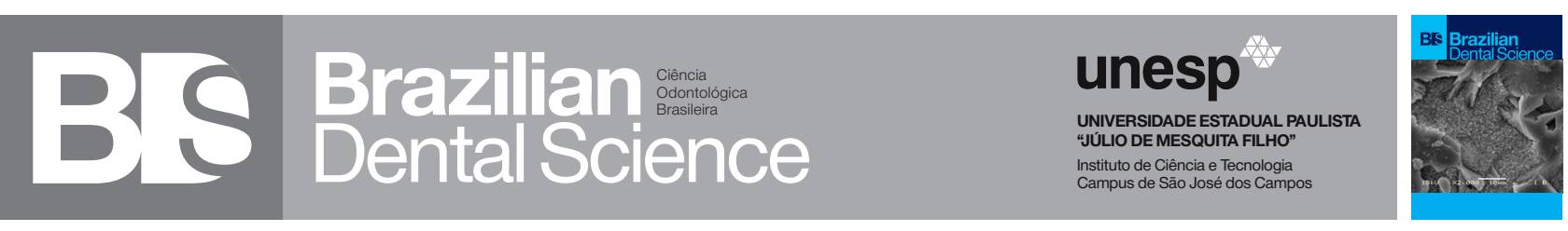

\title{
Treatment Outcomes Based on Patient's Oral Health Related Quality of Life (OHRQoL) after Receiving Conventional Clasp or Precision Attachment Removable Partial Dentures in Distal Extension Cases: A Randomized Controlled Clinical Trial
}

Resultado do tratamento com Prótese Parcial Removível convencional ou com encaixe de precisão, em casos de extremidade livre, baseado no índice de qualidade de vida relacionado á saúde bucal (OHROL): ensaio clínico controlado e randomizado

Rania Ibrahim MAMDOUH ${ }^{1}$, Nancy Nader EL-SHERBINI², Yusr Omar MADY²

1 - Faculty of Oral and Dental Medicine - Cairo University - Cairo - Egypt.

2 - Removable Prosthodontic Department - Cairo University - Cairo - Egypt.

\section{ABSTRACT}

Objective: To compare the effect of two treatment options in mandibular Kennedy class I cases regarding oral health related quality of life (OHRQoL) and the biting force, removable partial dentures retained by either precision attachment (PA-RPD) or clasps (C-RPD). Material and Methods: The study included 32 partially edentulous patients which 16 patients received PA-RPD (OT Cap Attachment) and 16 patients received C-RPD. All the patients in both groups were asked to fill the OHRQoL questionnaire after 1 week (baseline), 3 months, 6 months and 12 months after prosthesis insertion. Biting force was measured using the i-load Star Sensor one week, 3 months, 6 months and 1 year after partial denture insertion for all patients in both groups. Statistical analysis comprised Mann Whitney U test, Friedman's test, Dunn's test and Chisquare test. Results: The results of OHRQoL revealed that at the baseline, 3 months and 6 months the PA-RPD showed statistically significant lower mean total OHIP14 score than the C-RPD. However, after 12 Monthes, there was no statistically significant difference between total OHIP-14 scores in the two groups. Concerning the biting force there was no statistically significant difference between the two groups. Conclusion: Within the limitations of this study it was concluded that the OHRQoL of both the PA-RPD and the C-RPD was comparable after 12 months. Similarly the biting force was the same for both treatment options.

\section{KEYWORDS}

Removable partial denture; Clasps; Precision attachment; Structured questionnaires (OHIP-14).

\section{RESUMO}

Objetivos: Comparar o efeito de duas opções de tratamento (próteses parciais removíveis retidas por encaixe de precisão (PA-RPD) ou grampos (C-RPD) em casos de classe I inferiores de Kennedy em relação à qualidade de vida relacionada à saúde bucal (OHRQoL) e a força de mordida. Material e Métodos: $\mathrm{O}$ estudo incluiu 32 pacientes parcialmente desdentados, dos quais 16 receberam PA-RPD (OT Cap Attachment) e 16 pacientes receberam C-RPD. Todos os pacientes de ambos os grupos foram solicitados a preencher o questionário OHRQoL após 1 semana (linha de base), 3 meses, 6 meses e 12 meses após a inserção da prótese. A força de mordida foi medida usando o i-load Star Sensor uma semana, 3 meses, 6 meses e 1 ano após a inserção parcial da prótese em todos os pacientes dos dois grupos. A análise estatística compreendeu o teste U de Mann Whitney, teste de Friedman, teste de Dunn e teste do qui-quadrado. Resultados: Os resultados da OHRQoL revelaram que, no período basal, 3 meses e 6 meses, o PA-RPD apresentou um escore total médio mais baixo estatisticamente significativo do OHIP-14 do que o C-RPD. No entanto, após 12 meses, não houve diferença estatisticamente significante entre os escores totais do OHIP-14 nos dois grupos. Em relação à força de mordida, não houve diferença estatisticamente significante entre os dois grupos. Conclusão: Dentro das limitações deste estudo, concluiu-se que a OHRQoL do PARPD e do C-RPD era comparável após 12 meses. Da mesma forma, a força de mordida foi a mesma para as duas opções de tratamento.

\section{PALAVRAS-CHAVE}

Prótese parcial removível; Grampos; Encaixe de precisão; Questionários estruturados (OHIP-14). 


\section{INTRODUCTION}

$\mathrm{T}$ eeth loss is usually reflected on the general health condition, general wellbeing, and psychosocial behavior of the patients. The general health is affected due to the reduced intake of food caused by the reduced chewing ability that needs to be restored by the prosthesis together with the patient satisfaction. Partially edentulous patients especially the free end saddle cases as Kennedy Class I may be restored by implant fixed prosthesis or removable partial denture (RPD). Implants may not be a treatment option for some patients due to insufficient amount of bone, compromised general health conditions or economic reasons. Yet, removable partial denture (RPD) represents the most common treatment option for partial edentulism [1]. The conventional clasp retained RPD is considered the most feasible due to ease of fabrication, simplicity and low cost. However, the metal display of the clasp arm contributes to the unsatisfactory appearance for most of the patients [2]. RPD retained by attachments is an esthetic alternative to clasp-retained RPD [3].

Attachments are defined as a mechanical device for the fixation, retention and stabilization of the prosthesis. It consists of a metal receptacle and a closely fitting part. The former is the female component or the matrix. The latter, the closely fitting part, is the male component or the patrix [3].

The OT Cap attachment is an extra-coronal resilient ball and socket type of attachment which consists of a tooth retained male ball part cast with the crown to form assembly and snaps on female socket that is processed in the denture base either by direct or indirect technique of the attachment system. This type of attachment has five color-coded retentive caps with five different levels of retention. The clear color retentive cap which provides the standard retention was used with the black cap used during processing to prevent movement of the prosthesis [4].
Resilient attachment provides a defined amount and direction of movement of their component parts, permitting movement of the denture base towards the tissue under function. Theoretically, minimizing the amount of force transferred to the abutment teeth, thus acts as a "stress director and can be used in free end saddle cases [5]. The resilient type was preferred in the free end saddle cases as it provided some vertical movement and rotation of the denture base, thus it distributed the forces between the abutment tooth and the residual ridge [6-9]. The use of the extra-coronal attachments also had the advantage of directing the forces parallel to the long axis of the tooth improving retention, stabilization and maintaining the health of the periodontal tissues of the abutment teeth [10].

A prosthetic option should satisfy several criteria in which patient satisfaction and improving the quality of his life are among the priorities. Oral Health- Related Quality of Life (OHRQoL) is patient self-reported measures obtained by questionnaire determining different aspects of life. The questionnaire has seven conceptual and sequential domains: functional limitation, pain, psychological discomfort, physical disability, psychologic disability, social disability and handicap [11]. Biting force was measured for both prosthetic options to evaluate their effect on patient mastication and function.

Biting force level had been widely used in dentistry, mainly to understand the mechanics of mastication for evaluation of the therapeutic effects of the prosthetic devices and to provide reference values for studies on the biomechanics of prosthetic devices [12].

Persic S. et al. [13] concluded that the PARPD showed superior OHRQoL than C-RPD on the other hand Montero et. al. [14], found that metal-based removable partial dentures are the most predictable in terms of patient satisfaction.

Therefore, this study was conducted to compare the effect of the PA-RPD and the C-RPD 
as treatment options in partially edentulous Kennedy Class I cases regarding patient's quality of life and biting force values.

The hypothesis of this study was that there will be difference in OHRQoL and the Biting force between the PA-RPD and the C-RPD groups.

The study was registered on ClinicalTrials. gov Identifier: NCT02924142

\section{METHODS AND MATERIALS}

Ethical committee approval number: 34 1016

Based on the previous paper by Peršić, et al., 2015, [13] an expected absolute difference will be 6 with standard deviation 5 . A sample of 14 patients in each group will be sufficient to be able to reject the null hypothesis that the population means of the experimental and control groups are equal with probability (power) 0.85 . The Type I error probability associated with this test of this null hypothesis is 0.05 . This no is to be increased to 16 in each group to correct for non-parametric usage. The sample size was calculated by PS program.

Patients were selected from the outpatient clinic of the prosthodontic department, Faculty of Dentistry, Cairo University which utilizes "Patient Lists" for identifying and recruitment of potential subjects to the research. Once identified in the database, patients potentially eligible for this study were contacted, the study was explained and ascertains the patient's interest. Thirty two partially edentulous patients with an age range from $40-60$ years old were selected according to the following criteria:

- All patients had Kennedy Class I partially edentulous mandibular arch with the second premolar as the distal abutment bilaterally.

- Opposing dentition was intact arches with no noticeable over eruptions, tilting of teeth or edentulous spaces. Maxillary arches with properly designed and aligned fixed restorations were also included in the selected patients.

- Only patients with moderate to good oral hygiene status were selected.

- The abutment teeth with good periodontal condition with no signs of mobility or inflammation clinically with firm and healthy marginal and attached gingiva were selected.

- Mandibular edentulous ridges were covered by healthy firm muco-periosteum, without abnormal bony irregularities or severe lingual undercuts.

- Sufficient inter-arch space $(>8 \mathrm{~mm})$ between the residual lower ridge and the occlusal surface of the maxillary dentition was present.

- All patients had skeletal Angle's Class I maxillo-mandibular relation with no signs of tempro-mandibular joint disorders.

- Nonsmokers only were selected for the study with no history of parafunctional habits.

- All patients were selected with good general health, free from debilitating diseases or disorders affecting bone quality and quantity, facial nerves and muscles (e.g. diabetes mellitus, Parkinson disease, facial palsy).

- Patients who approved to be included in the trial signed a written consent.

- Gender of the patient wasn't considered.

\section{I- Patients Grouping}

Participants were assigned randomly to either experimental or control group allocated with a 1:1 sequence as per a computergenerated randomization schedule. A special website concerned with the randomization process called research randomizer (http:// www.randomizer.org.) was used by a third party who blindly set the intervention for each patient when contacted. The statistician and the dentists who assessed both outcomes were 
blinded about the study as well as the third party who did the randomization and the allocation concealment.

\section{Group I: The intervention group}

Sixteen patients received bilateral conventional removable partial denture retained by ball and socket extra-coronal precision attachment, the OT Cap attachment (OT Cap, Rhein 83, Bolona, Italy.).

Group II: The control group

Sixteen patients received bilateral conventional metallic removable partial denture retained by clasps.

\section{III-Prosthetic Phase}

\section{Group I}

\section{Prosthesis design}

The RPD was retained by OT Cap extracoronal attachment bilaterally joined by a lingual bar major connector. The male part of the attachment was attached to the distal surface of the abutment bridge and the female part (metal housing) was then cast with the metal framework of the RPD. A bracing lingual arm was designed in the

RPD bilaterally.

bilaterally:

Preparation of the abutment teeth

The lower first and second premolars on both sides were prepared with a deep chamfer finishing line that extends supra gingival by 0.5 $1 \mathrm{~mm}$ with sufficient occlusal reduction (2-2.5 $\mathrm{mm})$. Circumferential reduction on axial walls was performed $(1-1.5 \mathrm{~mm})$ for the abutments to receive a two unit porcelain fused to metal bridge on each side of the. A final impression was recorded using medium body rubber base impression (Zetaplus, Zermack, Italy.) on the mandibular special tray. assembly
After die preparation wax pattern was constructed using blue inlay wax (BEGO,

Germany.) as 2 unit bridge on the premolars bilaterally. A ledge was carved on the lingual surface of the second premolar wax pattern to receive a lingual bracing arm. Then, the male unit of the OT Cap attachment was attached to the distal surface of the second premolar wax pattern using the dental surveyor and run parallel to the residual ridge and above it by $1 \mathrm{~mm}$, positioning the attachment slightly lingual to the midline of the crest of the ridge. ( Figure 1)

The wax pattern of the bridge and the male part of the attachment was then sprued, invested, burnt-out and cast using Nickel-chromium alloy (Wironit, Bego, Western Germany.) as one unit to obtain the bridge-attachment assembly.

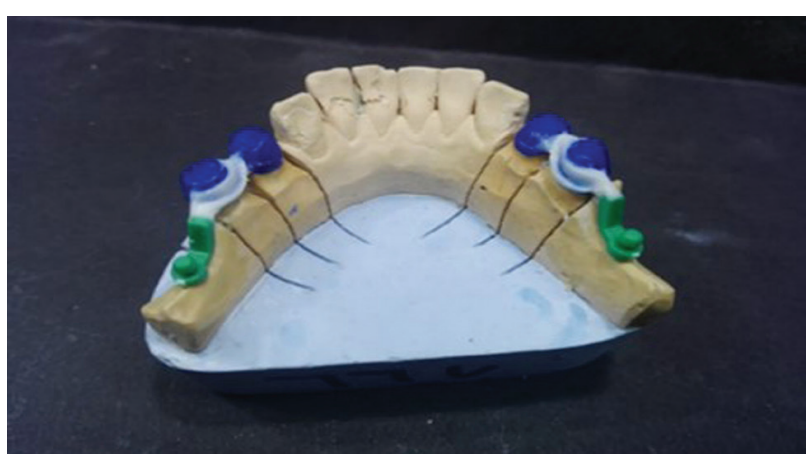

Figure 1 - Wax pattern of bridge-attachment assembly and slight lingual placement of the male part.

Metal try-in of the bridge-attachment assembly was performed intraorally. The porcelain (Vita Zahnfabric, Bad Sckingen, Germany.) was added matching the remaining natural teeth shade and the finished bridge attachment assembly was ready for insertion.

Pick-up of the attachment

The finished porcelain bridges with the male part attached to them were seated in the patient's mouth. After checking the bridgeattachment assembly and performing the 
necessary adjustments an overall alginate pickup impression was done. Separating medium was brushed in the fitting surface of the bridge and the impression was then poured in dental stone to obtain the master cast which was modified and duplicated into refractory cast.

On the refractory cast, wax pattern of the RPD framework was built-up according to the following design:

-The housing of the attachment was seated on the male part in which the wax pattern was attached.

-A combined meshwork denture base.

-Bracing arm resting on the ledge previously prepared on the lingual surface of the bridge.

-Lingual bar as a major connector.

The completed wax pattern was sprued, invested and cast into cobalt-chromium (Vita, Switzerland.) metal framework. Processing of the RPD was done. The retentive caps were snapped into the fitting surface of the denture using retentive caps inserting tool. Nylon caps of standard retention (clear color) ranging from $1000 \mathrm{gm}$ to $1100 \mathrm{gm}$ for the sphere were used. (Figure 2). The bridge-attachment assembly was permanently cemented using glassionomer cement ( Promedica, Neumunster, Germany.) the day before insertion of the RPD.

\section{Group II}

RPD design was a combination denture base, lingual bar as a major connector, gingivally approaching I-bar clasp for retention and Aker's bracing arm on second premolar tooth bilaterally, occlusal rest on the mesial aspect of the occlusal surface of the second premolar bilaterally and cingulum rests on the lingual surface of canines bilaterally. (Figure 3)

\section{IV-Patient's instructions}

Oral hygiene measures and denture care regimen were explained to all patients. All patients received the attachment retained RPD were recalled after 6 months of insertion for cap replacement.

\section{V-Patients Evaluation}

\section{A - Quality of life}

The shortened form (OHIP-14) questionnaire was used. All the patients in both groups were asked to fill the OHRQoF questionnaire after 1 week (baseline) 3 months,

6 months and 12 months after prosthesis insertion.

\section{B- Biting force}

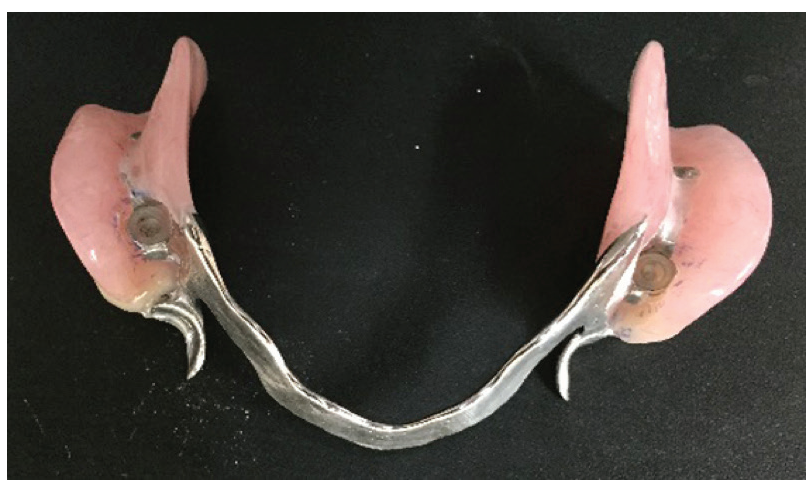

Figure 2 - Nylon caps inserted in the fitting surface of the RPD.

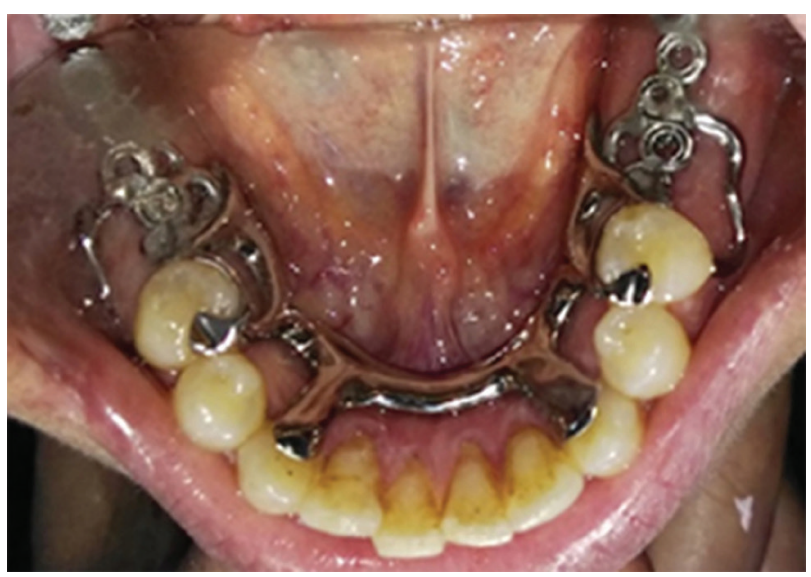

Figure 3 - Try in of metal framework. 
The Biting force was assessed using the i-load Star Sensor (i-load digital USB sensor, 453 Ravedale Drive, Mountain View. CA94043. USA.). Biting force was measured one week, 3 months, 6 months and 1 year after partial denture insertion for all patients in both groups.

The number of patients enrolled, randomized, allocated and analyzed throughout the whole study period is presented in CONSORT flow chart diagram. (Figure 4)

\section{Statistical Analysis}

Data were collected, statistically analyzed and illustrated in tables and figures. Numerical data were explored for normality by checking the distribution of data and using tests of normality Kolmogorov-Smirnov and Shapiro-Wilk tests (IBM Corporation, NY, USA.). All data showed non-normal (non-parametric) distribution except for age data. Data were presented as mean, standard deviation, median and range values. For non-parametric data; Mann Whitney $\mathrm{U}$ test was used to compare between the two groups. Friedman's test was used to study the changes by time within each group.

Dunn's test was used for pair-wise comparisons. For parametric data, Student's t-test was used to compare between the two groups.

Qualitative data were presented as frequencies and percentages. Chi-square test was used for comparisons between the groups.

The significance level was set at $\mathrm{P} \leq 0.05$. Statistical analysis was performed with IBM ${ }^{\circledR}$ SPSS ${ }^{\circledR}$ Statistics Version 20 for Windows (SPSS, Inc., an IBM Company.).

\section{RESULTS}

1-Total OHIP-14 scores (Table 1).

- At base line, there was a statistically significant difference between total OHIP14 scores in the two groups (P-value $=0.015$, Effect size $=0.431$ ). Group I showed statistically significantly lower mean total OHIP-14 score than Group II. - After 3 months, there was a statistically significant difference between total OHIP-14 scores in the two groups (P-value = 0.009 , Effect size $=0.461$ ). Group I showed statistically significantly lower mean total OHIP14 score than Group II.

- After 6 months, there was a statistically significant difference between total OHIP-14 scores in the two groups (P-value $=0.008$, Effect size $=0.467)$. Group I showed statistically significantly lower mean total OHIP-14 score than Group II.

- After 12 months, there was no statistically significant difference between total OHIP-14 scores in the two groups (P-value = 0.090, Effect size $=0.300$ ).

The change by time in Group I: There was a statistically significant change in total OHIP-14 scores by time (P-value $<0.001$, Effect size $=0.695)$. Pair-wise comparisons between the follow up times revealed that there was a statistically significant decrease in total OHIP14 scores from base line to 3 months as well as from 3 to 6 months. From 6 to 12 months, there was no statistically significant change in total OHIP-14 scores. (Table 2)

The change by time in Group II: Similarly, there was a statistically significant change in total OHIP-14 scores by time (P-value $<0.001$, Effect size $=0.712$ ). Pair-wise comparisons between the follow up times revealed that there was a statistically significant decrease in total OHIP14 scores from base line to 3 months as well as from 3 to 6 months. From 6 to 12 months, there was no statistically significant change in total OHIP-14 scores. (Table 2) 
Table 1 - Descriptive statistics and results of Mann-Whitney $U$ test for comparison between total OHIP-14 scores in the two groups

\begin{tabular}{|c|c|c|c|c|}
\hline Time & $\begin{array}{l}\text { Group I } \\
(n=16)\end{array}$ & $\begin{array}{l}\text { Group II } \\
(n=16)\end{array}$ & $P$-value & $\begin{array}{l}\text { Effect } \\
\text { size (r) }\end{array}$ \\
\hline \multicolumn{5}{|l|}{ Base line } \\
\hline Mean(SD) & $0.68(0.46)$ & $1.24(0.67)$ & $0.015^{\star}$ & 0.431 \\
\hline Median (Range) & $0.57(0-1.57)$ & $1.36(0-2.43)$ & & \\
\hline \multicolumn{5}{|l|}{3 months } \\
\hline Mean (SD) & $0.42(0.34)$ & $0.81(0.42)$ & $0.009^{\star}$ & 0.461 \\
\hline Median (Range) & $0.36(0-1)$ & $0.86(0-1.71)$ & & \\
\hline \multicolumn{5}{|l|}{6 months } \\
\hline Mean(SD) & $0.17(0.2)$ & $0.45(0.31)$ & $0.008^{\star}$ & 0.467 \\
\hline Median (Range) & $0.07(0-0.43)$ & $0.43(0-1)$ & & \\
\hline \multicolumn{5}{|l|}{12 months } \\
\hline Mean(SD) & $0.2(0.21)$ & $0.37(0.29)$ & 0.090 & 0.300 \\
\hline Median (Range) & $0.14(0-0.71)$ & $0.36(0-0.86)$ & & \\
\hline
\end{tabular}

Table 2 - Descriptive statistics and results of Friedman's test for comparison between total OHIP-14 scores at different follow up periods in each group

\begin{tabular}{|c|c|c|}
\hline Time & $\begin{array}{l}\text { Group I } \\
(n=16)\end{array}$ & $\begin{array}{l}\text { Group II } \\
(n=16)\end{array}$ \\
\hline \multicolumn{3}{|l|}{ Base line } \\
\hline Mean (SD) & $0.68(0.46)^{A}$ & $1.24(0.67)^{A}$ \\
\hline Median (Range) & $0.57(0-1.57)$ & $1.36(0-2.43)$ \\
\hline \multicolumn{3}{|l|}{3 months } \\
\hline Mean(SD) & $0.42(0.34)^{\mathrm{B}}$ & $0.81(0.42)^{B}$ \\
\hline Median (Range) & $0.36(0-1)$ & $0.86(0-1.71)$ \\
\hline \multicolumn{3}{|l|}{6 months } \\
\hline Mean (SD) & $0.17(0.2)^{c}$ & $0.45(0.31)^{\mathrm{C}}$ \\
\hline Median (Range) & $0.07(0-0.43)$ & $0.43(0-1)$ \\
\hline \multicolumn{3}{|l|}{12 months } \\
\hline Mean(SD) & $0.2(0.21)^{\mathrm{C}}$ & $0.37(0.29)^{c}$ \\
\hline Median (Range) & $0.14(0-0.71)$ & $0.36(0-0.86)$ \\
\hline$P$-value & $<0.001^{\star}$ & $<0.001^{\star}$ \\
\hline Effect size (w) & 0.695 & 0.712 \\
\hline
\end{tabular}

*: Significant at $\mathrm{P} \leq 0.05$, Different superscripts in the same column are statistically significantly different.

\section{2-Biting force (Table 3).}

Comparison between biting forces at the right and left sides revealed nonstatistically significant difference between the two sides; so the mean of the two sides was used for the comparisons.

- At base line, there was no statistically significant difference between biting force in the two groups $(\mathrm{P}$-value $=0.214$, Effect size $=$ 0.220 ).

- After 3 months, there was no statistically significant difference between biting force in the two groups $(\mathrm{P}$-value $=0.283$, Effect size $=$ 0.190).

- After 6 months, there was no statistically significant difference between biting force in the two groups (P-value $=0.200$, Effect size $=$ $0.226)$.

- After 12 months, there was no statistically significant difference between biting force in the two groups $(\mathrm{P}$-value $=0.474$, Effect size $=$ 0.127).

The change by time in Group I: There was a statistically significant change in biting force by time (P-value $<0.001$, Effect size $=0.517$ ) Pair-wise comparisons between the follow up times revealed that there was a statistically significant increase in biting force from base line to 3 months. From 3 to 6 as well as 6 to 12 months, there was no statistically significant change in biting force. (Table 4)

The change by time in Group II: Similarly, there was a statistically significant change in biting force by time (P-value $<0.001$, Effect size $=0.502$ ). Pair-wise comparisons between the follow up times revealed that there was a statistically significant increase in biting force from base line to 3 months. From 3 to 6 as well as 6 to 12 months, there was no statistically significant change in biting force. (Table 4) 
Table 3 - Descriptive statistics and results of Mann-Whitney $U$ test for comparison between biting forces in the two groups

\begin{tabular}{|ccccc|}
\hline Time & $\begin{array}{c}\text { Group I } \\
(\mathbf{n = 1 6 )}\end{array}$ & $\begin{array}{c}\text { Group II } \\
(\mathbf{n}=16)\end{array}$ & $\begin{array}{c}\boldsymbol{P} \text {-value } \\
\text { Base line }\end{array}$ Effect \\
size $(\boldsymbol{r})$
\end{tabular}

*: Significant at $\mathrm{P} \leq 0.05$

Table 4 - Descriptive statistics and results of Friedman's test for comparison between biting forces at different follow up periods in each group

\begin{tabular}{|c|c|c|}
\hline Time & $\begin{array}{l}\text { Group I } \\
(n=16)\end{array}$ & $\begin{array}{l}\text { Group II } \\
(n=16)\end{array}$ \\
\hline \multicolumn{3}{|l|}{ Base line } \\
\hline Mean (SD) & $259.1(102.3)^{\mathrm{B}}$ & $220.2(75.1)^{\mathrm{B}}$ \\
\hline Median (Range) & $241(105.5-502.5)$ & $218.3(114.5-409)$ \\
\hline \multicolumn{3}{|l|}{3 months } \\
\hline Mean(SD) & $294.7(107.1)^{A}$ & $259.8(66.7)^{A}$ \\
\hline Median (Range) & $281.5(125.5-555.5)$ & $253(177.5-430)$ \\
\hline \multicolumn{3}{|l|}{6 months } \\
\hline Mean (SD) & $310(111.9)^{A}$ & $262.4(63.7)^{\mathrm{A}}$ \\
\hline Median (Range) & $285.8(166-580)$ & $244.3(178-408)$ \\
\hline \multicolumn{3}{|l|}{12 months } \\
\hline Mean (SD) & $313.3(117.2)^{A}$ & $278.9(66.5)^{A}$ \\
\hline Median (Range) & $295.5(132.5-592.5)$ & $277.5(186-436.5)$ \\
\hline$P$-value & $<0.001^{\star}$ & $<0.001^{\star}$ \\
\hline Effect size (w) & 0.517 & 0.502 \\
\hline
\end{tabular}

*: Significant at $\mathrm{P} \leq 0.05$, Different superscripts in the same column are statistically significantly different.

\section{DISCUSSION}

The hypothesis of this study which stated that there will be difference in OHRQoL and the Biting force between the PA-RPD and the C-RPD groups was partialy accepted as the results showed that there will be difference from baseline till 12 months then after the first year there was no difference.

OT Cap attachment was used as it is simple and effective extra-coronal attachment designed for removable partial denture. The attachment has several advantages which preserves the abutment teeth and supporting structures in addition to patient satisfaction [14-16].

The major strength of this study was the assessment of the patients' self- reported measures related to the multidimensional construct, namely OHRQoL and using the

OHIP-14 questionnaire which measures seven dimensions for patient satisfaction. OHIP14 was used as it is reliable and validated in many countries and meets most clinical needs with good psychometric properties as it assess different physical, psychological and sociological dimensions of RPD therapy [17-19].

The results of this study showed significantly better after-treatment outcomes in both the precision attachment retained partial denture (PA-RPD) and the clasp retained partial denture (C-RPD) as was reported by patients verbal and in questionnaires. This was attributed to success of the removable partial denture (RPD) therapy in both groups; however, better outcomes (lower OHIP-14 score) were obtained among the PA-RPD patients compared to the C-RPD) patients. These results are in line with several studies which used different patients' self-reported measures including the OHIP-14 questionnaire [14,18,20-24].

The total OHIP-14 questionnaire scores revealed the superiority of the PA-RPD over the C-RPD which may be related to the increased patient acceptance to the tooth colored restorations more than the metal display which appeared on the distal abutment. Esthetics and 
the need for pretty and natural appearance increased nowadays among all age groups. This explained the great difference in the Psychological Disability dimension of the OHIP14 questionnaire between the PA-RPD and the C-RPD prosthesis [14].

Although there was no difference between the PA-RPD and the C-RPD concerning the other six dimensions of the OHIP-14 questionnaire yet this study revealed the superiority of the PA-RPD prosthesis in the patient satisfaction due to the improved esthetics. However, from the financial point of view C-RPD is superior to the PA-RPD and easier in construction and maintenance. The need to change of the nylon caps every 6 months as recommended by the manufacturer increases cost as well as number of post-operative visits [18].

Both the PA-RPD and the C-RPD revealed the same effect on the biting force.

However, there is a clinical relevance which shows the superiority of the PA-RPD over C-RPD that recommends its use. Although there was no statistically significant difference in biting force between the two types of prosthesis; yet PA-RPD group recorded higher mean biting force than the C-RPD group through the whole study period. This may be attributed to the retentive nature of the prosthesis which gave the patient more confidence during biting [25].

Both types of prosthesis revealed a significantly increase in the biting force from base line to the 3 months period while there was no increase from 3months to 6 months period as well as from 6 months to 12 months periods. This was expected and may be explained by the gradual building up of experience and patient adaptation to the prosthesis. This was in agreement with the results recorded by several studies, who concluded that regardless of the type of the prosthesis, patients usually function with their prosthesis much better after sometime, after they become "used to it" and "to their existence" in their mouths [1,26-28].

Using attachments in free end saddle cases provided splinting to the abutment teeth and provided esthetics when used in the anterior region. They achieved parallelism in case of non-parallel abutments by paralleling the attachments themselves not the abutments. The use of extra-coronal attachments could be more helpful than the claspretained RPD since they provided superior retention, better distribution of occlusal forces to the supporting structures and enhanced esthetics.

Difficult design which required high dental and laboratory skills, wear of the metal parts which resulted in loss of retention and high cost were among the main disadvantages.

Non-conservatism as each attachment needed reduction of two abutments minimum to receive full coverage splinted cast crowns, critical patient selection, sufficient interarch space as well as proper neuro-muscular coordination was within the limitations of this study.

Further studies needed to compare the precision attachment retained partial dentures with the thermoplastic removable partial denture.

\section{CONCLUSION}

Within the limitations of this study it was concluded that:

- The OHRQoL was improved for both PA-RPD and the C-RPD patients however, the PA-RPD was superior because of its esthetic appearance.

- The PA-RPD has same effect on biting force as compared to the C-RPD.

- The biting force record was increased by time till six months after insertion.

\section{CONFLICT OF INTEREST}

No potential conflict of interest relevant to this article was reported.

\section{FUNDING}

Self funded. 


\section{REFERENCES}

1. Carr, A, G,Brown D. McCracken's removable partial prosthodontics. 11ed. St,Louis: Elsevier.2011. p.11,19,32,116,175.

2. Zitzmann NU, Hagmann E, Weiger R. What is the prevalence of various types of prosthetic dental restorations in Europe? Clin Oral Implants Res. 2007 Jun;18 Suppl3:20-33.

3. The Academy of Prosthodontics. The glossary of prosthodontic terms. 9 ed. J ProsthetDent. 2017;117(5S):e1-e105.

4. GuptaN,Bhasin A, Gupta P,MalhotraP.Combined prosthesis with extracoronal castable precision attachments. Case Rep Dent. 2013;2013:282617.doi: 10.1155/2013/282617. Epub2013 Dec 9.

5. Burns DR, Ward JE. Review of attachments for removable partial denture design: 1.Classification and selection. Int J Prosthodont 1990 JanFeb;3(1):98-102.

6. Ku YC, Shen YF, Chan CP.Extracoronal resilient attachments in distal-extension removable partial dentures. Quintessence Int. 2000 May;31(5):311-7.

7. Dwivedi A, Vyas R, Gupta A. Quantitative evaluation and comparison of stress transmission characteristics of bar-clip and short coping overdenture attachments under dynamic loading: a photoelastic stress analysis. J Contemp DentPract. 2013 Mar 1; 14(2):287-92

8. Manju V,Sreelal T.Mandibular implant-supported overdenture: an in vitro comparison of ball, bar, and magnetic attachments. J Oral Implantol. 2013 Jun;39(3):302-7. doi: 10.1563/AAID-JOI-D-11-00050. Epub 2012 Aug 14.

9. Previgliano V,Monfrin SB, Notaro V, Preti G. A new coping for overdentures Part 1: A pilot study of the marginal precision. Int J Prosthodont. $2007 \mathrm{Mar}$ Apr;20(2):159-60.

10. Den Haan R, Battistuzzi PG, Witter DJ, de BaatC, Creugers NH. (Semi-)precision attachments for cast metal frame removable partial dentures. Ned Tijdschr Tandheelkd. 2011Feb;118(2):93-100.

11. Slade GD, Spencer AJ. Development and evaluation of the Oral Health Impact Profile.Community Dent Health. 1994 Mar;11(1):3-11.

12. Fernandes CP,Glantz POJ, Svensson SA, Bergmark A. A novel sensor for bite force determinations. Dent Mater.2003 Mar;19(2):118-26.

13. PeršićS, Kranjčić J, Pavičić DK, Mikić VL, Čelebić A. Treatment Outcomes Based on Patients' Self-Reported Measures after Receiving New Clasp or Precision Attachment-Retained Removable Partial Dentures. J Prosthodont. 2017 Feb;26(2):115-122. doi:10.1111/jopr.12395. Epub 2015 Nov30.

14. Montero J, Castillo-Oyagüe R, Lynch CD, Albaladejo A, Castaño A. Selfperceived changes in oral health-related quality of life after receiving different types of conventional prosthetic treatments: A cohort follow-up study. JDent. 2013 Jun;41(6):493-503. doi: 10.1016/j.jdent.2013.01.006. Epub2013 Jan 23.
15. Munot VK, Nayakar RP,Patil R. Prosthetic Rehabilitation of Mandibular Defects with Fixed-removable Partial Denture Prosthesis Using Precision Attachment: A Twin Case Report. Contemp Clin Dent. 2017 Jul-Sep;8(3):473-478. doi: 10.4103/ccd.ccd_117_17.

16. Wang $\mathrm{H}$, Zhang $\mathrm{Y}, \mathrm{Yao} \mathrm{D}$, Chen J. Effects of rigid and nonrigid extracoronal attachments on supporting tissues in extension base partial removable dental prostheses: a nonlinear finite element study.J Prosthet Dent. 2011 May;105(5):338-46. doi:10.1016/S0022-3913(11)60066-8.

17. Slade GD. Derivation and validation of a short-form oral health impact profile. Accessed 2017.Community Dent Oral Epidemiol. 1997 Aug;25(4):284-90.

18. Locker D, Matear D, Stephens M, Lawrence H, Payne B. Comparison of the GOHAl and OHIP-14 as measures of the oral health-related quality of life of the elderly. Community Dent Oral Epidemiol. 20010ct;29(5):373-81.

19. Locker $D$, Allen F. What do measures of 'oral health-related quality of life' measure? Community Dent Oral Epidemiol. 2007 Dec;35(6):401-11.

20. Roborel de Climens A, Tunceli K, Arnould B, Germain N, Iglay K, Norquist $J$, etal. Review of patient-reported outcome instruments measuring health-related quality of life and satisfaction in patients with type 2 diabetes treated with oral therapy. Curr Med Res Opin. 2015 Apr;31(4):643-65. doi: 10.1185/03007995.2015.1020364. Epub2015 Mar 16.

21. Khalid T, Yunus N, lbrahim N, Elkezza A, Masood M. Patient-reported outcome and its association with attachment type and bone volume in mandibular implant overdenture. Clin Oral Implants Res. 2017 May;28(5):535-542. doi: 10.1111/clr.12831. Epub 2016 Mar 17.

22. Donovan TE, Cho GC. Esthetic considerations with removable partial dentures. JCalifDent Assoc. 2003 Jul;31(7):551-7.

23. Jenkins G. Precision attachments. Part 1: Treatment planning and classification. Dent Tech. 1992 Mar;45(3):1-4,6.

24. Vaidya S, Kapoor C, Bakshi Y, Bhalla S. Achieving an esthetic smile with fixed and removal prosthesis using extracoronal castable precision attachments. J Indian Prosthodont Soc. 2015 Jul-Sep;15(3):284-8. doi: 10.4103/09724052.155048

25. Miyaura K, Morita M, Matsuka Y, Yamashita A, Watanabe T. Rehabilitation of biting abilities in patients with different types of dental prostheses. J Oral Rehabil.2000 Dec;27(12):1073-6.

26. Tumrasvin W, Fueki K, Ohyama T.Factors Associated with Masticatory Performance in Unilateral Distal Extension Removable Partial Denture Patients. JProsthodont 2006 Jan-Feb;15(1):25-31.

27. Kukunoor S, Savadi RC, Venkata Krishnam Raju K, Kumar S. A Viable Treatment Alternative in Distal Extension Cases: A Case Report. J Indian Prosthodont Soc. 2014 Dec;14(Suppl 1):177-80. doi: 10.1007/s13191-012-0218-6. Epub2012Dec2.

28. Phoenix R, Canga, D, DeFreest C. Stewart's Clinical Removable partial prosthodontics. 3 ed. Chicago, Berlin, Tokyo, Copenhagen: Quintessence Publishing Co.2003.

Rania Ibrahim Mamdouh (Corresponding address)

Faculty of Oral and Dental Medicine - Egyptian Russian University - Cairo

- Egypt

Badr City, Cairo-Suez road, Postal Code 11829

Date submitted: 2019 Jul 03

E-mail: rtmohamza2004@outlook.com Accept submission: 2019 Sep 06 